\title{
THE STUDY OF SERUM PROTEINS AND LIPIDS WITH THE AID OF THE QUANTITY ULTRACENTRIFUGE. I. PROCEDURE AND PRINCIPAL FEATURES OF THE CENTRIFUGATE OF UNTREATED NORMAL SERUM AS DETERMINED BY QUANTITATIVE ANALYSIS OF SAMPLES FROM TEN LEVELS ${ }^{\mathbf{1 , 2}}$
}

\author{
BY ROY H. TURNER, JOHN ROBERT SNAVELY, WILLIAM H. GOLDWATER, \\ MALCOLM L. RANDOLPH, CHARLES C. SPRAGUE, AND WALTER G. UNGLAUB \\ (From the Department of Medicine, School of Medicine and the Biophysics Laboratory, Tulane \\ University of Louisiana, New Orleans, La.)
}

(Submitted for publication March 16, 1951 ; accepted July 30, 1951)

The studies described in this paper and some which follow have as an objective a better description of serum lipids. The present paper represents the first detailed report of work begun early in 1948, some features of which have been published in abstract (1-5). Initially our purpose was to extend the observations of Recant, Chargaff and Hanger (6) on the influence of serum proteins upon the cephalin-cholesterol flocculation and the thymol turbidity tests. We included quantitative analyses of the centrifugate for lipids as well as for proteins. It soon became apparent that we were using a procedure which was useful in the study of the structure and function of lipid complexes.

As shown in the review by Edsall (7) there has long been evidence that a large proportion of the lipids of the serum occur not as small molecules, but as lipid aggregates, or lipoproteins, of varying complexity. The use of the ultracentrifuge, both quantitative and analytical, has a well established place in the study of serum lipids. Important contributions have been made by $\mathrm{McF}$ arlane $(8,9)$, Pedersen $(10,11)$, the Harvard group (12), Gofman and the Berkeley group (13-17), and more recently by others (18-20).

The Berkeley workers have effectively used both the quantity and analytical ultracentrifuge in the study of serum lipids and have established exacting technics for the use of the analytical ultracentrifuge in the description of lipid complexes by measure-

1 This work was done in part under a contract from the Office of the Surgeon General, U. S. Army, and under the sponsorship of the Commission on Liver Disease, Armed Forces Epidemiological Board.

2 Some of the data in this paper were presented at the Tenth Liver Injury Conference of the Josiah Macy, Jr. Foundation on May 21, 1951. ment of rate of flotation when suspended in a standard medium, a technic which we have not used. Principal emphasis in published studies by other workers has been on centrifugation of treated serum. In the present paper we deal exclusively with centrifugation of untreated whole serum. At present it does not seem profitable to attempt a detailed comparison between the results obtained by our procedure on the one hand and those obtained by the system of analysis introduced by Cohn and his associates (21), and the results of the flotation procedures of others. When our studies of diseased states and normal individuals under dietary stress have been presented, such comparisons will be in order. Some of the similarities of our contributions to those of others will be mentioned below in the discussion.

The perfect procedure for the study of serum proteins and lipids in the initial step would give complete separation of the different lipid and protein complexes, each entity in pure state with structure unchanged by the procedure effecting separation. We doubt if the procedure described in this communication separates any single lipid or protein complex in pure form; nevertheless, the concentration of complexes at certain levels in the centrifugate is of such a degree as to give new information concerning the structure of the complexes at that level and their concentration in the serum under study. The lipid distribution curves are reproducible within satisfactory limits with normal sera, and are significantly different in certain diseased states, especially in acute virus hepatitis, as we have already reported briefly (3) and will report later in detail. We believe our procedure has three main advantages: The manipulation of serum which effects redistribution of pro- 
teins and lipids is gentle and involves minimal risk of damage to complex molecules; description of samples is by multiple quantitative methods; and an integrated picture of the protein and lipid compositions of whole serum is provided. The obvious disadvantages are that the method requires a large sample of serum, expensive apparatus and much time of highly trained workers.

\section{MATERIALS AND METHODS}

The data reported in the present paper were obtained by study of sera from 14 normal young men, either medical students or members of the laboratory staff, who were apparently in excellent health. Chemical analyses of whole serum for the constituents under study fell within the normal range as determined in our laboratory. From an original group of 16 subjects, two were eliminated because the estimations on the whole serum for neutral fat exceeded by more than 3 standard deviations the mean of the 16. Blood was drawn in the morning after a 12-hour fast, the subject usually having been instructed to eat no fat-rich food the preceding evening. The serum was stored at $4^{\circ} \mathrm{C}$. until the following day, when centrifugation was performed. Commonly, three or more tubes were filled with a single serum so that several sera, including at least one normal and one abnormal, were centrifuged at one time. The Beams type air-driven ultracentrifuge was used with a rotor holding 12 plastic tubes, each of one-half inch diameter and $8.2 \mathrm{ml}$. capacity, set at an angle of $10^{\circ}$ from the axis of rotation $(22,23)$. The centrifugation was performed at a speed of 800 revolutions per second, producing a mean centrifugal force of 130,000 G., for four hours, with about 23 minutes for acceleration and from 75 to 110 minutes for deceleration. The standard speed was maintained with an error of less than $1 \%$ by hand regulation guided by an oscillographic speed indicator. A vacuum of less than 0.0005 $\mathrm{mm}$. $\mathrm{Hg}$ was maintained about the rotor, which had a temperature of about $28^{\circ} \mathrm{C}$. After the rotor had coasted to a stop and had been removed from the vacuum chamber, the plastic tubes containing the centrifugate were carefully removed and sampled.

The objective in sampling was to obtain reproducible sezments from the column so that centrifugate from corresponding levels of tubes of the same serum might be pooled for analysis and samples from comparable levels of different sera might be compared. Hughes, Pickels and Horsfall used the quantity ultracentrifuge for the study of the sedimentation properties of serum proteins and separated the centrifugate into six samples (24). Previously we employed a sampling technic of quick freezing of the centrifugate and cutting the frozen column on a lathe (25). However, for the work now being reported, we have used a device for sampling liquids which obviates the difficulties of thermal convection, and possible denaturation of lipoproteins by freezing. This device drives a thin pointed knife blade horizontally through the walls of a vertically clamped plastic tube and through the column of liquid centrifugate at successively measured levels in such a fashion that the blade forms a sealed bottom to

TABLE I

Principal features of centrifugate according to density zones

\begin{tabular}{|c|c|c|c|c|c|c|c|c|}
\hline $\begin{array}{l}\text { Descriptive } \\
\text { term for } \\
\text { density } \\
\text { zones }\end{array}$ & $\begin{array}{l}\text { Composition } \\
\text { according to } \\
\text { sampling } \\
\text { technic and } \\
\text { vol. in } \\
6 \text { tubes }\end{array}$ & $\begin{array}{c}\text { Vol., } \\
\% \\
\text { whole } \\
\text { column }\end{array}$ & $\begin{array}{l}\text { Range, } \\
\text { \%o } \\
\text { column } \\
\text { ht. }\end{array}$ & $\begin{array}{l}\text { Sp. gr. } \\
\text { range }\end{array}$ & $\begin{array}{c}\text { Physical } \\
\text { appearance }\end{array}$ & $\begin{array}{l}\text { Protein } \\
\text { content, } \\
\% \text { total } \\
\text { in cen- } \\
\text { trifugate }\end{array}$ & $\begin{array}{l}\text { Total } \\
\text { lipids } \\
\text { content, } \\
\% \text { total } \\
\text { in cen- } \\
\text { trifugate }\end{array}$ & $\begin{array}{c}\text { Distinguishing chemical } \\
\text { characteristics }\end{array}$ \\
\hline $\begin{array}{l}\text { Minimum } \\
\text { density }\end{array}$ & $\begin{array}{l}\text { No. } 1=5.71 \\
\text { Top sample }\end{array}$ & 12 & $88-100$ & $\begin{array}{l}1.000 \\
1.004\end{array}$ & $\begin{array}{l}\text { Top is } \\
\text { creamy }\end{array}$ & 0.3 & 21 & Rich in neutral fat \\
\hline $\begin{array}{l}\text { Minimum } \\
\text { concentration }\end{array}$ & No. $2=7.00$ & 14 & $74-88$ & $\begin{array}{l}1.004- \\
1.010\end{array}$ & $\begin{array}{l}\text { Water } \\
\text { clear }\end{array}$ & 0.9 & 5 & $\begin{array}{l}\text { Inconstant with usual } \\
\text { procedure; poor in pro- } \\
\text { teins and lipids }\end{array}$ \\
\hline $\begin{array}{l}\text { Low-medium } \\
\text { density }\end{array}$ & 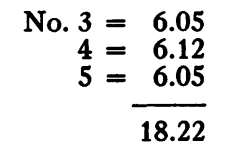 & 37 & $37-74$ & $\begin{array}{l}1.010- \\
1.028\end{array}$ & $\begin{array}{l}\text { Turbid } \\
\text { band }\end{array}$ & 18.0 & 44 & $\begin{array}{l}\text { High concentration all } \\
\text { lipid constituents }\end{array}$ \\
\hline $\begin{array}{l}\text { High-medium } \\
\text { density }\end{array}$ & $\begin{aligned} \text { No. } 6=6.12 \\
7=3.17 \\
8=3.17 \\
12.46\end{aligned}$ & 25 & $12-37$ & $\begin{array}{l}1.028- \\
1.055\end{array}$ & $\begin{array}{l}\text { Clear } \\
\text { dark } \\
\text { yellow }\end{array}$ & 40.7 & 22 & $\begin{array}{l}\text { All lipid constituents well } \\
\text { represented except free } \\
\text { cholesterol }\end{array}$ \\
\hline $\begin{array}{l}\text { High } \\
\text { density }\end{array}$ & 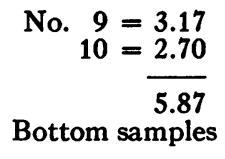 & 12 & $0-12$ & $\begin{array}{l}1.055- \\
1.110\end{array}$ & $\begin{array}{l}\text { Clear } \\
\text { brownish } \\
\text { yellow }\end{array}$ & 40.0 & 7 & $\begin{array}{l}\text { Phospholipids and neu- } \\
\text { tral fat only important } \\
\text { lipids; high concentra- } \\
\text { tion globulins }\end{array}$ \\
\hline
\end{tabular}


the segment of tube above that level (26). The contents of the tube above the blade are drawn into a syringe through a No. 20 gauge needle. The theoretical volumes of our 10 standard samples of centrifugate are shown in Table I.

During centrifugation the components of serum tend to form cylindrical layers about the axis of rotation. During deceleration and while the tubes stand vertically before sampling, these layers assume a new transverse arrangement in the tubes. The success of sampling depends upon this reorientation. That a rearrangement does occur is evident from gross inspection. The top cream layer and various bands of color and turbidity at different levels, sometimes seen as low in the tube as $15 \%$ column height, are sharply defined and horizontal. Such a reorientation of layers is not always perfect as is shown by the observation during sampling of highly viscous protein material concentrated at the peripheral side of the bottom of the tube. In a few instances the bottom sample has been divided by cutting vertically and the outer fraction showed significantly higher concentration of protein than the inner. On the side of the tube toward the axis of rotation there is sometimes observed a thin projection downward of part of the creamy material from the top of the column. This has not been observed after prolonged centrifugation.

\section{CHEMICAL METHODS}

Total protein and albumin values were based on microKjeldahl nitrogen determinations (27), using a factor of 6.25 to convert nitrogen to protein. Albumin-globulin separations were accomplished by saturation with $\mathrm{MgSO}_{4}$, using the technic employed by Popjak and McCarthy (28), and albumin nitrogen was determined on the filtrates. Non-protein nitrogen determinations on tungstic acid filtrates of a series of samples of ultracentrifugate showed all to have concentrations of 30 to $40 \mathrm{mg} . \%$, with no appreciable deviations from normal values for whole serum. Accordingly, a corresponding value of $0.2 \mathrm{gm} . \%$ was uniformly subtracted from the total protein and albumin values obtained by total nitrogen determinations. ${ }^{2}$

Specific gravity determinations were done by the falling-drop method of Barbour and Hamilton (29). Whenever concentrated protein solutions from the lower layers of the centrifugate were diluted with $0.85 \% \mathrm{NaCl}$ solution to facilitate their manipulation, the specific gravity of the diluted specimen was corrected for the saline dilution, using 1.0045 as the density of the saline, a value obtained by pycnometer and falling-drop technics.

All lipid analyses were performed on extracts of the samples in 24 volumes of ethanol-ether, $3: 1$ by volume. Cholesterol determinations were done by the Schoen-

\footnotetext{
2 In some instances when $0.2 \mathrm{gm} . \%$ was subtracted from the albumin concentration based upon nitrogen estimations in the Popjak filtrate, negative values resulted. In such cases the albumin concentrations were taken as zero, and the globulin values accordingly equal the total protein concentration.
}

heimer-Sperry technic (30), with some modifications suggested by Sobel and Mayer (31). Ester cholesterol values were converted to cholesterol esters via the factor 1.67, assuming a molecular weight of 277 for average serum fatty acids (32). Lipid phosphorus was determined on aliquots of the lipid extract evaporated to dryness in a hot water bath and digested with perchloric acid (33), with color development according to the method of Fiske and SubbaRow (34). A factor of 25 was used to convert values for lipid phosphorus to phospholipid. Fatty acid determinations were done following a method (35) based on the Man and Gildea modification (36) of the older Stoddard and Drury technic (32). To calculate neutral fat, there have been assumed to be $2 \mathrm{mEq}$. of fatty acids per mole of lipid phosphorus, and $1 \mathrm{mEq}$. per mole of cholesterol ester. The total of these values is subtracted from the figure for total fatty acids, to give neutral fat fatty acid concentrations in milliequivalents. Multiplying this quantity by 290 gives the milligrams of neutral fat, assuming the average serum fatty acid molecular weight of 277. By expressing as neutral fat the fatty acids which are found in excess of those attributable to the phospholipids and cholesterol esters determined, we do not exclude the possibility that significant quantities of fatty acids may be present in some other form, such as free fatty acids, or else not measured by the method used, as would be true for short-chain water-soluble fatty acids. Total lipid values are a summation of the individual lipid concentrations-free cholesterol, cholesterol esters, phospholipids, and neutral fat.

\section{GRAPHS}

The graphs (Figures 1 and 2) present the mean concentrations of different constituents versus volume of centrifugate, as measured from the bottom of the tube. The plotted points represent the mean values in each of the 10 standard samples per serum and are placed at the midpoint in theoretical volume for each sample. Smooth curves have been drawn to yield the same content in each sample as the measured mean value for that sample, but the curves do not necessarily pass through the plotted points. Concentrations in the top sample, which is far from homogeneous because it contains the lipid-rich cream layer, are represented by rectangular bars. The content of a given material of any sample or selected volume of the tube is directly proportional to the area under the appropriate curve and between the chosen limits of volume. Water-soluble compounds unaffected by ultracentrifugation would appear on such graphs as nearly horizontal lines, similar to one representing concentration of water. This is approximately what happens with non-protein nitrogen, sodium and potassium.

At certain levels the shape of the curves we have drawn is influenced by the volume of the samples. This is well illustrated by the two top zones contained in samples 1 and 2 , the upper one of which contains the cream layer. Our graphs present the mean concentration for the entire top sample, whereas in fact less than one-third of the No. 1 sample constitutes the concentrated creamy ma- 


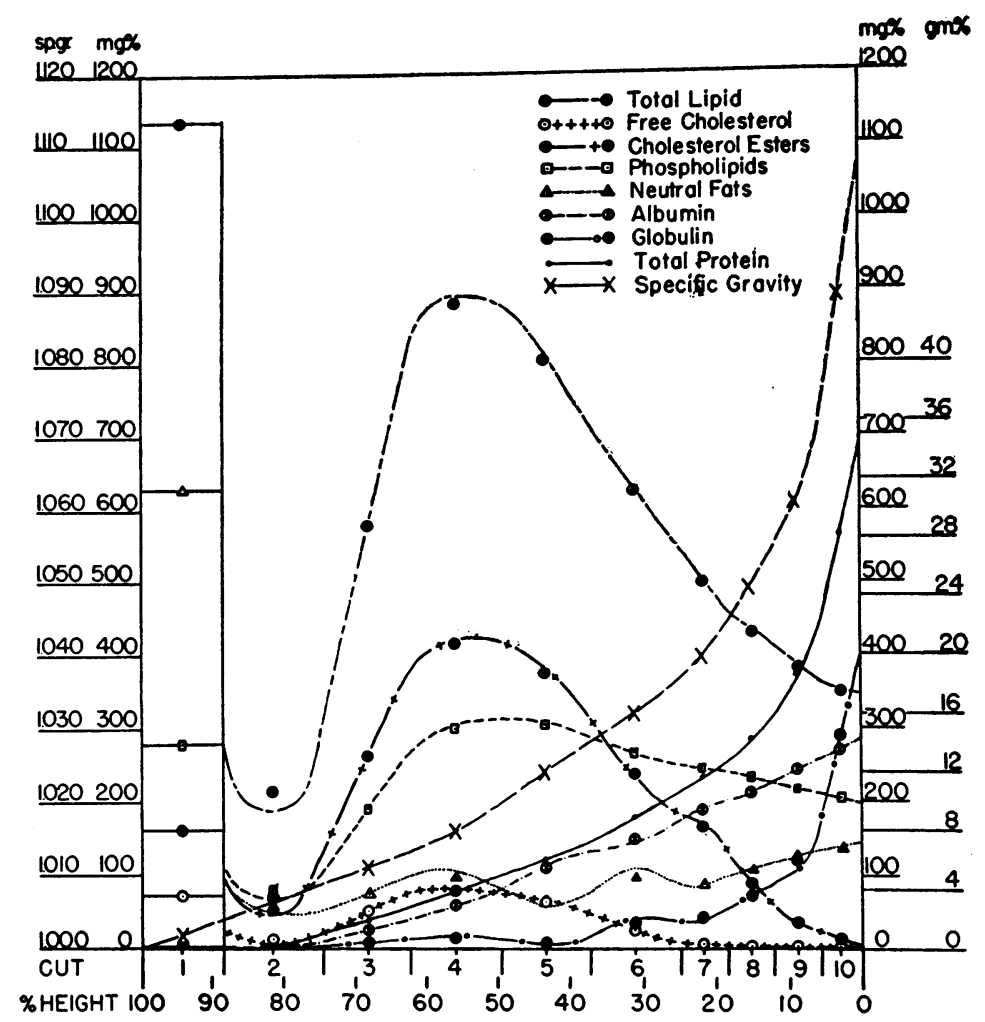

Fig. 1. Protein and Lipid Composition of Ultracentrifugate of Normal Serum Spun for Eight Hours at 800 R.P.S. (See Text), Based on Mean Curves for 14 Sera

Concentrations shown in mg. per $100 \mathrm{ml}$., except for proteins which are in gms. per $100 \mathrm{ml}$. First row of figures at the bottom opposite "cut" is number of sample, the boundary of each sample being indicated by the lines between these numbers. Bottom row of figures, 0 to 100 , represents either $\%$ of volume of column of centrifugate, or $\%$ of column height, assuming a flat bottom for the tube.

terial at the top of the liquid column. When we had divided sample 1 of normal serum into two equal parts, the creamy upper half was found to contain nearly all the lipid constituents and the clear lower half resembled the No. 2 sample. In some pathologic sera the clear lower part of the top sample contains a high concentration of lipids.

Because of minute leaks and coating of apparatus and glassware, our sampling technic introduces some volumetric losses, part of which may consist of material from either the upper or lower portion of a given sample. In our construction of graphs we have assumed that the volume of centrifugate lost from each sample contained mean concentrations of all the constituents measured in that sample. The magnitude of errors from this assumption is not, in our opinion, a cause for concern with our current objectives.

\section{RESULTS AND DISCUSSION}

The effects of ultracentrifugation of untreated normal serum are best visualized by inspection of the mean curves of distribution in Figures 1 and 2 and a summary of principal features of the centrifugate in Table I. The description of centrifugate in this paper, unless otherwise stated, is based on the mean curves. The greatest changes in concentration as a result of four hours of centrifugation are found at the bottom and top of the tube where globulin and neutral fat, respectively, are concentrated. As shown in Figure 2, globulin is concentrated about seven times in the bottom sample and neutral fat less than four times in the top sample. With prolonged centrifugation globulin concentration in the bottom sample may be 12 times that of the original serum and total lipids at one level are concentrated five and a half times (Figure $3)$.

The concentration of total proteins and, in paral- 
lel, values of specific gravity increase at a progressively increased rate from the top sample with 0.3 $\mathrm{gm} . \%$ to the bottom sample of the column with 28 gms. $\%$, the latter concentration being about 90 times the former. The distribution curves for albumin are simpler in form than those for globulin in keeping with the evidence that albumin is the more homogeneous. In the top one-quarter of the column and in a narrower zone at the bottom globulin concentration exceeds that of albumin; as shown in Figure 2, there is a peak concentration of globulin slightly over the mid-point of the column in association with concentration of various lipids. We believe that much of these globulins in the upper two-thirds of the column are protein constituents of lipoproteins. We will present results of electrophoresis of centrifugate in a later report.

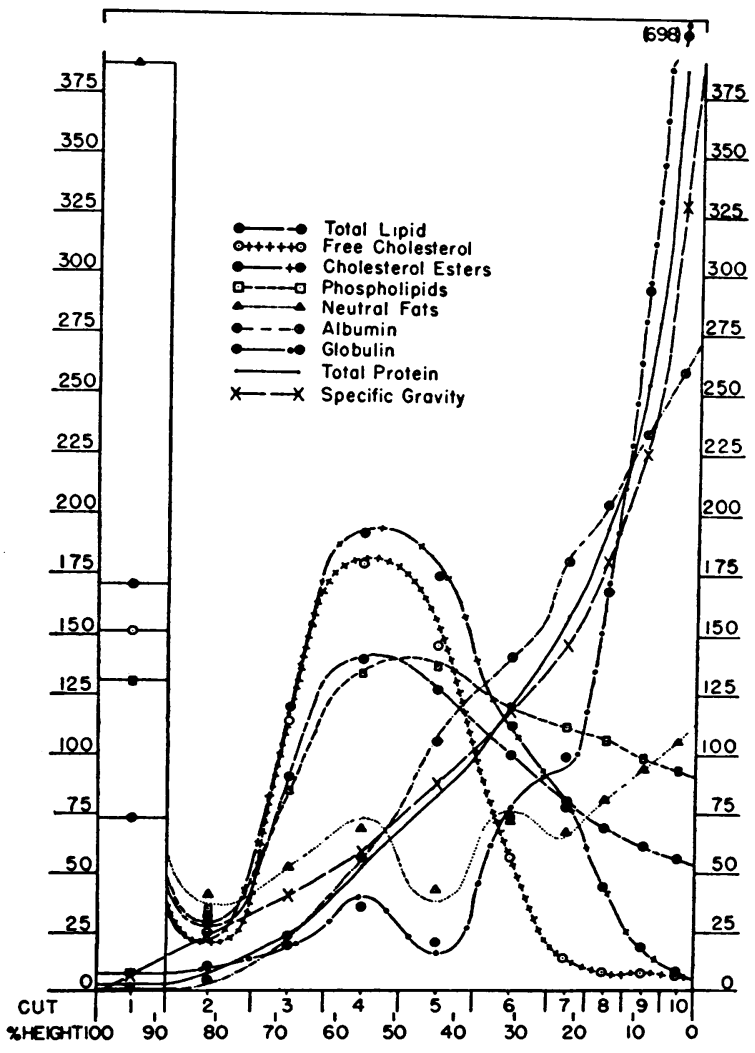

Fig. 2. Same Data as in Fig. 1, Except Composition of the Centrifugate is Expressed Relattve to the Composition of the Whole Serum

In expressing specific gravity as \% of original serum, only those figures to the right of the decimal point have been used.

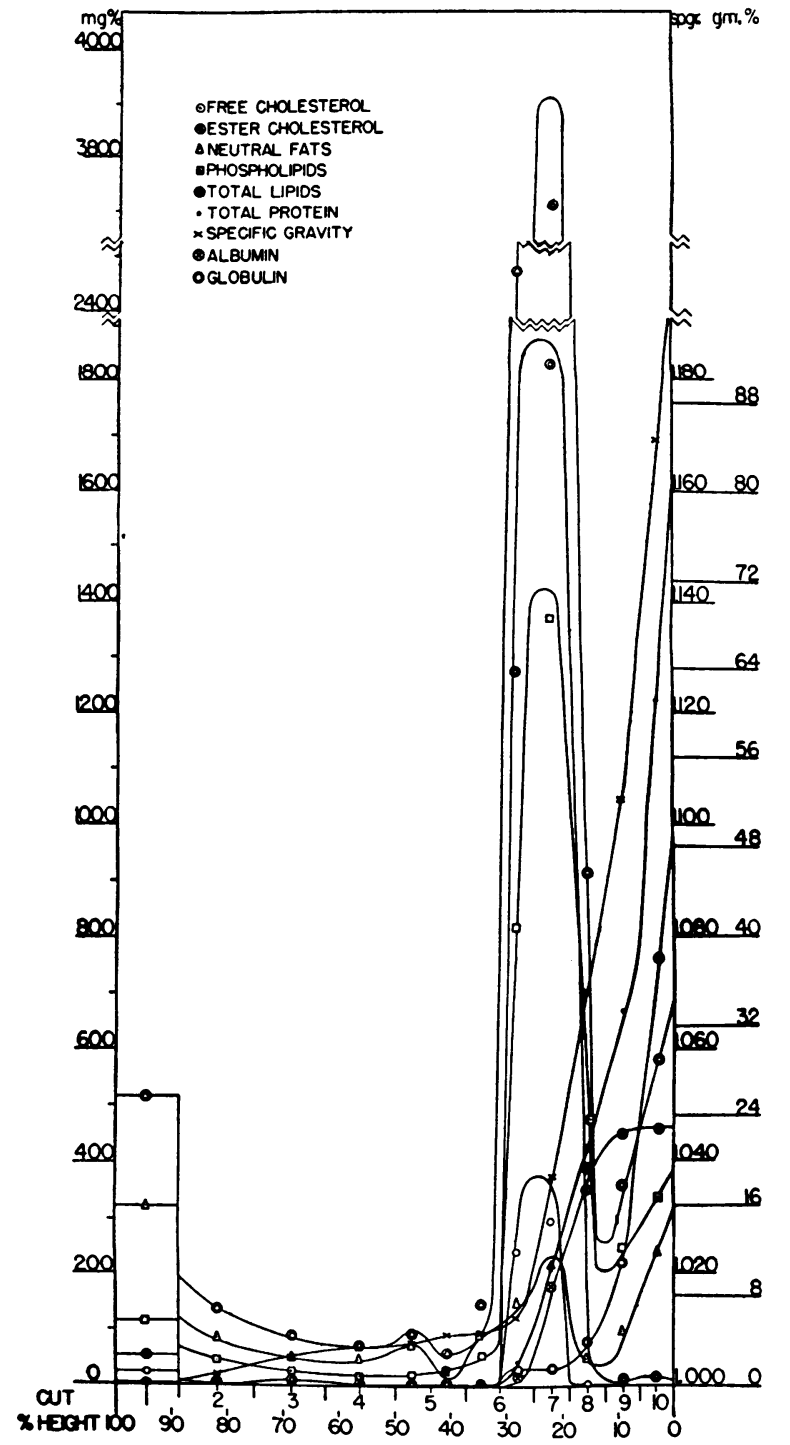

Fig. 3. Protein and Lipid Composition of Ultracentrifugate of a Single Normal Serum Spun for 16 HourS AT 800 R.P.S.

The mean curves of distribution for the individual lipid components show varying degrees of individuality. In general the similarities in form are greater in the upper half of the column while extreme differences are found in the lower half. Shown in Table $I$ are the distinctive physical and chemical features of five zones of increasing density from the top of the column:1) Minimum density. 2) Minimum concentration. 3) Lowmedium density. 4) High-medium density. 5) High density. The zone of minimum density contains $21 \%$ of the total lipids and consists of two 
layers, the upper and narrower of creamy material containing chylomicrons, or lipomicrons. The lower and larger layer is a clear liquid, which in its chemical composition resembles that described below for the zone of minimum concentration. Because it is not feasible to separate these two layers exactly while sampling and because we know that the sample consists of two grossly different parts, we represent the contents of this zone by rectangular areas in our graphs. It cannot be assumed for pathologic serum that the lower clear layer in this zone is low in lipid concentration as we have so far found it in the normal. Neutral fat is the principal lipid component but there are significant concentrations of both free and esterified cholesterol and phospholipids. There are moderately exact mathematical interrelationships among these four lipids.

The distinctive features of the centrifugate in the zone of minimum concentration no doubt result from the movement out of this zone of nearly all of the lipids and proteins in one direction or the other. The zone may be greatly broadened and the composition simplified by prolonging the centrifugation for more than four hours. One normal serum has been centrifuged for eight hours and another for 16 at our usual speed (see Figure 3). Eight samples from the zone of minimum concentration of these two centrifugates showed the following mean values : specific gravity 1.006 (maximum 1.009, minimum 1.002), globulins $0.15 \mathrm{gm} . \%$ (maximum 0.20, minimum 0.10), phospholipids $29 \mathrm{mg} . \%$ (maximum 48, minimum 18), neutral fat $46 \mathrm{mg} . \%$ (maximum 84, minimum 21 ) and insignificant concentrations of cholesterol and albumin. In five of the 14 normal sera subjected to our standard technic, which showed lowest concentrations of lipids in the No. 2 samples, this zone had a composition which resembled that of the broadened zone, having the same mean specific gravity, similar concentrations of free cholesterol and neutral fat, slightly higher values for phospholipids, but considerably higher for cholesterol esters. We believe that prolonged centrifugation reveals distinctive characteristics not discernible when the usual technic of centrifugation is employed.

Two main possibilities are suggested to explain these findings: One is that the lipids remaining in this zone after prolonged centrifugation consist of small molecules, little influenced by centrifugation. If this proves to be the correct explanation, distribution throughout the column would give greater quantities of this material than are now apparent. The other possibility is that large molecules containing these lipids have the observed distribution because of their density. Lindgren, Elliott, and Gofman have published in graphic form the results of similarly prolonged centrifugation of untreated serum (17). Our graph in Figure 3 shows a number of similarities to and differences from theirs.

The two zones of medium density meet at the level where the specific gravity of the centrifugate is that of normal serum. The zone of low-medium density is the zone of largest volume and contains $44 \%$ of the total lipids of normal serum and a still greater proportion of phospholipids and cholesterol, particularly the free form. The lipids found in the zone of high-medium density are characterized by the sparsity of free cholesterol and the predominance of phospholipids and cholesterol esters, and $22 \%$ of the total serum lipids are found in this zone. The zone of high density is characterized by extremely high concentration of proteins and by the extreme sparsity of cholesterol in any form. The significant lipid constituents here are phospholipids and neutral fat, both of which are found in concentrations approximating that of whole serum. Twenty-one $\%$ of the serum total lipids are found in this zone.

We believe from study of data presented in this paper that there are at least five different lipid complexes in normal serum, one entity for each of the five density zones, which gives to that portion of the centrifugate distinctive chemical features. The lipoproteins characteristic of the three lowest zones show a marked degree of overlapping distribution among the three zones. This concept will be further developed in reports which follow.

The degrees of variability in concentration of proteins and lipids in 14 normal sera and in 10 samples for each corresponding centrifugate are shown in Table II. The frequency distribution curve of concentrations at each sampling level usually shows skew because one or more high values causes a long tail on the curve, as is commonly observed in statistical analyses of a small number of samples. The standard deviation of the mean con- 
TABLE II

Mean, standard deviation of the mean, maximum and minimum values of measurements made on whole serum and 10 samples of centrifugates of sera from 14 healthy young men

In column under " $S$ " are values for whole serum and beneath the numbers 1-10 (in columns 1-10) are values for centrifugate samples serially from top to bottom of the column.

\begin{tabular}{|c|c|c|c|c|c|c|c|c|c|c|c|c|}
\hline & & $\mathbf{S}$ & 1 & 2 & 3 & 4 & 5 & 6 & 7 & 8 & 9 & 10 \\
\hline Sp. gr. & $\begin{array}{l}\text { Mean } \\
\text { S.D. } \\
\text { Max. } \\
\text { Min. }\end{array}$ & $\begin{array}{l}1.027 \\
0.001 \\
1.029 \\
1.026\end{array}$ & $\begin{array}{l}1.002 \\
0.003 \\
1.007 \\
0.997\end{array}$ & $\begin{array}{l}1.007 \\
0.002 \\
1.009 \\
1.004\end{array}$ & $\begin{array}{l}1.011 \\
0.002 \\
1.014 \\
1.008\end{array}$ & $\begin{array}{l}1.016 \\
0.002 \\
1.021 \\
1.013\end{array}$ & $\begin{array}{l}1.024 \\
0.002 \\
1.027 \\
1.021\end{array}$ & $\begin{array}{l}1.032 \\
0.002 \\
1.036 \\
1.028\end{array}$ & $\begin{array}{l}1.040 \\
0.002 \\
1.044 \\
1.036\end{array}$ & $\begin{array}{l}1.049 \\
0.003 \\
1.053 \\
1.045\end{array}$ & $\begin{array}{l}1.061 \\
0.005 \\
1.072 \\
1.055\end{array}$ & $\begin{array}{l}1.089 \\
0.004 \\
1.097 \\
1.083\end{array}$ \\
\hline $\begin{array}{l}\text { Total } \\
\text { prot.* } \\
\text { gms. \% }\end{array}$ & $\begin{array}{l}\text { Mean } \\
\text { S.D. } \\
\text { Max. } \\
\text { Min. }\end{array}$ & $\begin{array}{l}7.25 \\
0.30 \\
7.67 \\
6.90\end{array}$ & $\begin{array}{l}0.21 \\
0.14 \\
0.46 \\
0.01\end{array}$ & $\begin{array}{l}0.47 \\
0.30 \\
0.98 \\
0.10\end{array}$ & $\begin{array}{l}1.69 \\
0.73 \\
3.29 \\
0.85\end{array}$ & $\begin{array}{l}3.72 \\
0.63 \\
4.81 \\
2.70\end{array}$ & $\begin{array}{l}5.97 \\
0.47 \\
6.52 \\
5.13\end{array}$ & $\begin{array}{l}8.78 \\
0.56 \\
9.55 \\
7.96\end{array}$ & $\begin{array}{r}11.60 \\
0.76 \\
12.74 \\
10.54\end{array}$ & $\begin{array}{r}14.29 \\
0.81 \\
15.64 \\
12.79\end{array}$ & $\begin{array}{r}18.35 \\
1.45 \\
21.64 \\
16.81\end{array}$ & $\begin{array}{r}28.23 \\
1.63 \\
30.68 \\
25.84\end{array}$ \\
\hline $\begin{array}{l}\text { Alb., } † \\
\text { gms. } \%\end{array}$ & $\begin{array}{l}\text { Mean } \\
\text { S.D. } \\
\text { Max. } \\
\text { Min. }\end{array}$ & $\begin{array}{l}5.16 \\
0.35 \\
5.70 \\
4.61\end{array}$ & $\begin{array}{l}0.13 \\
0.18 \\
0.53 \\
0.00\end{array}$ & $\begin{array}{l}0.25 \\
0.17 \\
0.53 \\
0.02\end{array}$ & $\begin{array}{l}1.25 \\
0.65 \\
2.52 \\
0.47\end{array}$ & $\begin{array}{l}2.94 \\
0.73 \\
3.92 \\
2.00\end{array}$ & $\begin{array}{l}5.46 \\
0.37 \\
5.91 \\
4.61\end{array}$ & $\begin{array}{l}7.39 \\
0.45 \\
8.11 \\
6.75\end{array}$ & $\begin{array}{r}9.41 \\
0.60 \\
10.76 \\
8.94\end{array}$ & $\begin{array}{r}10.64 \\
1.13 \\
12.58 \\
9.12\end{array}$ & $\begin{array}{r}12.16 \\
1.24 \\
14.74 \\
10.84\end{array}$ & $\begin{array}{r}13.50 \\
1.68 \\
16.33 \\
10.90\end{array}$ \\
\hline $\begin{array}{l}\text { Glob.,† } \\
\text { gms. } \%\end{array}$ & $\begin{array}{l}\text { Mean } \\
\text { S.D. } \\
\text { Max. } \\
\text { Min. }\end{array}$ & $\begin{array}{l}2.11 \\
0.41 \\
2.74 \\
1.60\end{array}$ & $\begin{array}{l}0.16 \\
0.05 \\
0.45 \\
0.00\end{array}$ & $\begin{array}{l}0.23 \\
0.10 \\
0.45 \\
0.06\end{array}$ & $\begin{array}{l}0.42 \\
0.14 \\
0.77 \\
0.23\end{array}$ & $\begin{array}{l}0.74 \\
0.35 \\
1.27 \\
0.29\end{array}$ & $\begin{array}{l}0.46 \\
0.27 \\
0.82 \\
0.13\end{array}$ & $\begin{array}{l}1.50 \\
0.37 \\
1.95 \\
0.99\end{array}$ & $\begin{array}{l}2.10 \\
0.66 \\
3.30 \\
1.36\end{array}$ & $\begin{array}{l}3.62 \\
1.35 \\
5.28 \\
1.92\end{array}$ & $\begin{array}{l}6.07 \\
0.99 \\
7.50 \\
4.41\end{array}$ & $\begin{array}{r}14.47 \\
1.82 \\
17.80 \\
12.42\end{array}$ \\
\hline $\begin{array}{l}\text { A/G } \\
\text { ratio }\end{array}$ & $\begin{array}{l}\text { Mean } \\
\text { S.D. } \\
\text { Max. } \\
\text { Min. }\end{array}$ & $\begin{array}{l}2.55 \\
0.62 \\
3.56 \\
1.79\end{array}$ & $\begin{array}{l}0.29 \\
0.56 \\
1.18 \\
0.00\end{array}$ & $\begin{array}{l}1.39 \\
0.75 \\
2.17 \\
0.00\end{array}$ & $\begin{array}{l}2.93 \\
1.04 \\
4.65 \\
1.24\end{array}$ & $\begin{array}{r}5.41 \\
3.75 \\
10.90 \\
1.93\end{array}$ & $\begin{array}{r}13.83 \\
12.81 \\
44.00 \\
4.33\end{array}$ & $\begin{array}{l}5.46 \\
1.77 \\
8.33 \\
3.87\end{array}$ & $\begin{array}{l}4.85 \\
1.59 \\
7.91 \\
2.86\end{array}$ & $\begin{array}{l}3.52 \\
1.94 \\
6.27 \\
1.96\end{array}$ & $\begin{array}{l}2.05 \\
0.47 \\
2.97 \\
1.58\end{array}$ & $\begin{array}{l}0.95 \\
0.21 \\
1.31 \\
0.72\end{array}$ \\
\hline $\begin{array}{l}\text { Free } \\
\text { cholest., } \\
m g . \%\end{array}$ & $\begin{array}{l}\text { Mean } \\
\text { S.D. } \\
\text { Max. } \\
\text { Min. }\end{array}$ & $\begin{array}{l}43.7 \\
14.4 \\
71.4 \\
27.4\end{array}$ & $\begin{array}{r}69.9 \\
48.7 \\
161.0 \\
3.2\end{array}$ & $\begin{array}{r}12.9 \\
11.6 \\
40.5 \\
0.7\end{array}$ & $\begin{array}{l}51.3 \\
23.4 \\
91.4 \\
22.5\end{array}$ & $\begin{array}{r}78.3 \\
21.9 \\
109.9 \\
37.6\end{array}$ & $\begin{array}{l}62.8 \\
14.3 \\
91.8 \\
36.7\end{array}$ & $\begin{array}{r}24.8 \\
9.6 \\
40.2 \\
7.7\end{array}$ & $\begin{array}{r}5.8 \\
4.6 \\
17.4 \\
0.0\end{array}$ & $\begin{array}{l}3.5 \\
2.9 \\
7.8 \\
0.0\end{array}$ & $\begin{array}{r}3.4 \\
3.2 \\
10.8 \\
0.0\end{array}$ & $\begin{array}{l}2.7 \\
2.6 \\
7.6 \\
0.0\end{array}$ \\
\hline $\begin{array}{l}\text { Cholest. } \\
\text { esters, } \\
m g . \%\end{array}$ & $\begin{array}{l}\text { Mean } \\
\text { S.D. } \\
\text { Max. } \\
\text { Min. }\end{array}$ & $\begin{array}{r}215 \\
46 \\
282 \\
148\end{array}$ & $\begin{array}{r}161 \\
119 \\
296 \\
12\end{array}$ & $\begin{array}{r}68 \\
50 \\
165 \\
0\end{array}$ & $\begin{array}{l}262 \\
108 \\
446 \\
134\end{array}$ & $\begin{array}{l}415 \\
104 \\
547 \\
257\end{array}$ & $\begin{array}{r}374 \\
72 \\
548 \\
268\end{array}$ & $\begin{array}{r}237 \\
37 \\
266 \\
175\end{array}$ & $\begin{array}{r}163 \\
22 \\
200 \\
114\end{array}$ & $\begin{array}{r}89 \\
40 \\
151 \\
12\end{array}$ & $\begin{array}{r}35 \\
35 \\
95 \\
2\end{array}$ & $\begin{array}{r}13 \\
16 \\
35 \\
0\end{array}$ \\
\hline $\begin{array}{l}\text { P-lipids, } \\
m g . \%\end{array}$ & $\begin{array}{l}\text { Mean } \\
\text { S.D. } \\
\text { Max. } \\
\text { Min. }\end{array}$ & $\begin{array}{r}222 \\
32 \\
280 \\
170\end{array}$ & $\begin{array}{l}278 \\
129 \\
465 \\
105\end{array}$ & $\begin{array}{r}79 \\
39 \\
169 \\
41\end{array}$ & $\begin{array}{r}190 \\
63 \\
318 \\
117\end{array}$ & $\begin{array}{r}298 \\
60 \\
395 \\
208\end{array}$ & $\begin{array}{r}303 \\
36 \\
340 \\
251\end{array}$ & $\begin{array}{r}265 \\
29 \\
296 \\
192\end{array}$ & $\begin{array}{r}244 \\
16 \\
268 \\
208\end{array}$ & $\begin{array}{r}231 \\
16 \\
270 \\
205\end{array}$ & $\begin{array}{r}216 \\
21 \\
355 \\
190\end{array}$ & $\begin{array}{r}203 \\
40 \\
313 \\
143\end{array}$ \\
\hline $\begin{array}{l}\text { Neut. fat, } \\
m g . \%\end{array}$ & $\begin{array}{l}\text { Mean } \\
\text { S.D. } \\
\text { Max. } \\
\text { Min. }\end{array}$ & $\begin{array}{r}161 \\
73 \\
287 \\
46\end{array}$ & $\begin{array}{r}749 \\
440 \\
1,684 \\
148\end{array}$ & $\begin{array}{r}55 \\
25 \\
110 \\
23\end{array}$ & $\begin{array}{r}77 \\
36 \\
142 \\
15\end{array}$ & $\begin{array}{r}98 \\
58 \\
197 \\
32\end{array}$ & $\begin{array}{r}67 \\
43 \\
139 \\
0\end{array}$ & $\begin{array}{r}99 \\
53 \\
221 \\
32\end{array}$ & $\begin{array}{r}90 \\
33 \\
148 \\
15\end{array}$ & $\begin{array}{r}109 \\
56 \\
194 \\
17\end{array}$ & $\begin{array}{r}127 \\
39 \\
194 \\
64\end{array}$ & $\begin{array}{r}138 \\
43 \\
223 \\
67\end{array}$ \\
\hline $\begin{array}{l}\text { Total } \\
\text { lipids, } \\
m g . \%\end{array}$ & $\begin{array}{l}\text { Mean } \\
\text { S.D. } \\
\text { Max. } \\
\text { Min. }\end{array}$ & $\begin{array}{l}635 \\
155 \\
911 \\
463\end{array}$ & $\begin{array}{r}1,247 \\
678 \\
2,494 \\
326\end{array}$ & $\begin{array}{r}215 \\
101 \\
440 \\
82\end{array}$ & $\begin{array}{l}579 \\
204 \\
900 \\
331\end{array}$ & $\begin{array}{r}883 \\
228 \\
1,176 \\
543\end{array}$ & $\begin{array}{r}807 \\
122 \\
1,034 \\
600\end{array}$ & $\begin{array}{r}626 \\
75 \\
769 \\
530\end{array}$ & $\begin{array}{r}502 \\
48 \\
589 \\
432\end{array}$ & $\begin{array}{r}433 \\
64 \\
536 \\
335\end{array}$ & $\begin{array}{r}382 \\
39 \\
467 \\
334\end{array}$ & $\begin{array}{r}352 \\
53 \\
460 \\
279\end{array}$ \\
\hline
\end{tabular}

* On 10 sera.

† On 8 sera.

centration at each of the 10 levels sampled indicates the over-all variability attributable to technical errors of centrifugation, sampling and analytical measurement as well as the physiologic variation in concentration of proteins and lipids in a small group of healthy young men. With so many important sources of variability we are of the opinion that the reproducibility of distribution curves for our different components in the normal serum is remarkably high. In general, reproducibility is greater in the lower half of the column. The lowest standard deviation expressed as per cent of the mean concentration is found in the No. 5 sample for free cholesterol, in the No. 7 sample for phospholipids, ester cholesterol and total proteins, in the No. 6 sample for albumin, in one 
of the two bottom samples for neutral fat, and globulin. In general, reproducibility of curves of distribution is of the same order as reproducibility of a given measurement for whole serum in descending order: specific gravity, total protein, albumin, phospholipids, globulin, cholesterol ester, free cholesterol and neutral fat. No doubt, the large technical error in estimation of neutral fat contributes to its poor reproducibility.

We have examined our data to determine what portion of the centrifugates contributed most to variation in concentration of the different lipid components in normal whole serum. Samples from any given tube level should contribute to variability of concentration of a given component in whole serum in proportion to the magnitude of the standard deviation of mean content of that component in the sample. The three highest values for any one lipid among the 10 samples were found in either the zone of minimum or of lowmedium density.

The most reasonable explanation for the peculiarities in distribution of lipids we are reporting is that they are associated with proteins and that their behavior under high centrifugal forces is influenced by peculiarities of both protein and lipid components and by the quantity and characteristics of non-lipid proteins present in the serum. The role of the protein portion of the complex in determining the localization in the centrifugate seems especially important for those in the lower levels. We believe an important mechanism in the distribution of lipids depends upon the behavior of a lipid complex when surrounded by media of differing density. The sedimentation of proteins results in a gradient of density of the surrounding medium, which varies from specific gravity of about 1.006 at the top to one of about 1.110 at the bottom. Certain lipid complexes, with densities between these limits, tend to become concentrated at their own density level by both flotation from lower levels and sedimentation from higher portions of the column. This concept was first suggested by one of us (J. R. S.) early in 1949 because the peak concentration of lipids in the zone of low-medium density, particularly that of free cholesterol, tended to appear in centrifugate of about the same specific gravity, regardless of length of centrifugation and original specific gravity of the whole serum (2).
Gofman and associates arrived at a similar concept from study of analytical ultracentrifuge patterns. Our observations with different technic and data confirm the basic principle described by the Berkeley workers whose publication (13) preceded ours. Although the importance of the protein density gradient in determining localization of certain lipoproteins in the ultracentrifugate of whole serum is now well established, we still lack accurate expression of the relationship between density of suspending medium and lipid complex at various levels in the column. There is evidence that the specific gravity of the two may differ significantly after four hours of centrifugation, in spite of the tendency toward equality. Certainly at the top of the column the lipid complexes are less dense than the suspending medium. Our study of correlation between specific gravity and total protein concentration of the centrifugate shows the presence of a non-protein solution with specific gravity of 1.006 (37). Furthermore, estimations of concentration of sodium and potassium at various levels gave values within the normal range for whole serum. Our observation that the specific gravity of centrifugate of our top sample is approximately that of water can only be explained by the presence of lipid aggregates having a lower specific gravity than that of the medium in which they are suspended. Lindgren, Elliott and Gofman have reported that chylomicrons and other lipid particles have a specific gravity of less than 1.006 (17). Obviously the two ends of the column represent a special condition where lipid complexes may be stopped while moving toward their own density levels. We have measured the density of lipid complexes in the zone of lowmedium density and find their densities to be slightly higher than that of the suspending medium (38).

The possibility remains that the lipid distribution patterns observed might be due in part to accumulations of non-protein lipid aggregates at some levels. That this is not the case, with the possible exception of the cream layer, however, is strongly suggested by the observation that the lipid aggregates with the greatest proportion of the lipid of highest density, cholesterol, occur relatively high in the tube, while those complexes containing the greatest proportions of low density 
lipids, neutral fat and phospholipids, occur deep in the tube at high density levels.

Evidence that the described technic for the use of the quantity ultracentrifuge achieves a high degree of differentiation of lipid complexes are: 1) The individuality of curves of distribution for the different lipid components, and as a consequence extreme variations in different samples in relationships which in normal whole serum tend to great constancy, such as ratios of esterified to free cholesterol, and cholesterol to lipid phosphorus (39). 2) Marked tendency to constancy of interrelationship among lipid components in each of five top samples. This evidence will be presented in detail later. One of the important methods for differentiation of lipoproteins does not show differences between fractions in the proportions of free and esterified cholesterol (40).

The observation that the four lipid constituents estimated, free and esterified cholesterol, phospholipids and neutral fat, were all found in high concentration slightly above the middle of the column and that in the layers beneath, first free then esterified cholesterol approached or reached zero concentration, although the others remained at high levels, is interpreted as evidence that some serum lipoproteins contain cholesterol in the esterified form only and others are completely lacking in cholesterol. The existence of such lipoproteins, as far as we are aware, has not been previously pointed out. Albrink, Man and Peters, in a recent study of the lipids of whole serum (41), presented mathematical evidence that might be interpreted as indicating the presence of a moiety of lipid phosphorus which is not associated with free cholesterol.

It is entirely possible that better differentiation of lipoproteins may be achieved when the redistribution of large molecules by high centrifugal forces has reached equilibrium than is possible by our usual four hour technic, as is shown in Figure 3. When centrifugation is prolonged, however, the proteins, including the lipoproteins, are forced into such a small fraction of the tube and reach such high concentration there that two difficulties may interfere with exploitation of the possible advantages : accurate collection of thin layers of centrifugate and imperfect reorientation of layers when centrifugation ends.

\section{SUM MARY}

1. A procedure for the study of untreated human serum with the quantity ultracentrifuge is described, in which the column of ultracentrifugate is sampled at 10 levels and analyzed by quantitative methods for proteins and lipids.

2. Detailed results of analyses of centrifugate and whole serum of 14 healthy young men are shown in tables, which also indicate over-all variability of concentration due to errors of physical method, sampling, analytical technics, and physiologic variables. In graphs are presented mean curves of distribution in the column of centrifugate of specific gravity, total protein, albumin, globulin, free and esterified cholesterol, phospholipids, and neutral fat. A similar graph shows results of prolonged centrifugation.

3. The principal features of the centrifugate are shown by the characteristics of five zones of increasing density: (a) Zone of minimum density at the top of the column; neutral fat is the principal constituent ; content highly variable, representing about one-half of whole serum neutral fat. (b) Zone of minimum concentration; poor in proteins and lipids; inconstant composition with usual centrifugation. (c) Zone of low-medium density, not exceeding that of normal serum; a broad zone centering above the mid-point of the column; moderate increase in concentration over whole serum of all lipid constituents measured, except neutral fat; contains nearly one-half the lipids in the serum. In this zone more than in any other are the lipids, excepting neutral fat, principally responsible for the variation in concentration of such lipids in normal serum. (d) Zone of highmedium density, exceeding that of normal serum; contains little free cholesterol, but the esterified form is present in disproportionately great concentration. (e) Zone of high density at the bottom, with the highest concentration of proteins; especially rich in globulins, and contains little cholesterol in any form, but with concentrations of phospholipids and neutral fat approximating that of whole serum.

4. The distribution of lipids in the column of centrifugate is greatly influenced by the protein density gradient, the characteristics of which in normal serum depend upon the choice of mean 
centrifugal force and time of centrifugation. In the standard procedure described, the density gradient and distribution of proteins and lipids is adapted to present limitations of sampling.

5. The distribution of lipids in the lower portion of the centrifugate shows the presence there of serum lipoproteins containing either phospholipids or neutral fat, or perhaps both; in one type the cholesterol is only of the esterified form, and in the other there is no cholesterol whatever.

\section{ACKNOWLEDGMENTS}

We are deeply indebted to Professor Huldah Bancroft for advice about the statistical studies, to Dr. Chas. A. Jones for estimations of sodium and potassium, to Miss Jane Armstrong, Mrs. Sara Correll, Miss Beatrice Gaupp and Mrs. Laurette Gauthier, who carried out the chemical analyses, and to Mr. H. C. Daubert, Jr., and Mr. Riley R. Ryan, who assisted with the ultracentrifuge.

\section{REFERENCES}

1. Goldwater, W. H., Randolph, M. L., Snavely, J. R., Turner, R. H., and Unglaub, W. G., Ultracentrifugal stratification of human serum lipoproteins. Federation Proc., 1950, 9, 178.

2. Snavely, J. R., Goldwater, W. H., Randolph, M. L., Sprague, C. C., and Unglaub, W. G., Study of human serum based on analysis of fractions obtained in the quantity ultracentrifuge. J. Clin. Invest., 1950, 29, 847.

3. Turner, R. H., Goldwater, W. H., Randolph, M. L., Sprague, C. C., Snavely, R., and Unglaub, W. G., Study of blood serum with the quantity ultracentrifuge with particular reference to serum fat and lipids in hepatitis. Tr. A. Am. Physicians, 1950, 63, 230.

4. Goldwater, W. H., Randolph, M. L., Snavely, J. R., and Turner, R. H., Chemical and isotopic tracer studies of human serum lipoproteins with the aid of the quantity ultracentrifuge. Federation Proc., 1951, 10, 190.

5. Snavely, J. R., Goldwater, W. H., Randolph, M. L., Sprague, C. C., and Unglaub, W. G., The lipid composition of ultracentrifugates of normal human serum in the post-absorptive state. J. Clin. Invest., 1951, 30, 674 .

6. Recant, L., Chargaff, E., and Hanger, F. M., Comparison of the cephalin-cholesterol flocculation with the thymol turbidity test. Proc. Soc. Exper. Biol. \& Med., 1945, 60, 245.

7. Edsall, J. T., The plasma-proteins and their fractionation, in Advances in Protein Chemistry, Anson, M. L., and Edsall, J. T., editors. Academic Press, New York, 1947, Vol. III, p. 384.

8. McFarlane, A. S., An ultracentrifugal investigation of the serum proteins. Biochem. J., 1935, 29, 407.
9. McFarlane, A. S., The ultracentrifugal protein sedimentation diagram of normal human, cow and horse serum. Biochem. J., 1935, 29, 660.

10. Pedersen, K. O., Ultracentrifugal Studies on Serum and Serum Fractions. Almqvist \& Wiksells, Uppsala, 1945.

11. Pedersen, K. O., Low-density lipoprotein appearing in normal human plasma. J. Phys. \& Coll. Chem., 1947, 51, 156.

12. Oncley, J. L., Gurd, F. R. N., and Melin, M., Preparation and properties of serum and plasma proteins. $\mathrm{XXV}$. Composition and properties of human serum $\beta$-lipoprotein. J. Am. Chem. Soc., 1950, 72, 458.

13. Gofman, J. W., Lindgren, F. T., and Elliott, H., Ultracentrifugal studies of lipoproteins of human serum. J. Biol. Chem., 1949, 179, 973.

14. Lindgren, F. T., Elliott, H. A., Gofman, J. W., and Strisower, B., The ultracentrifugal composition of normal rabbit serum. J. Biol. Chem., 1950, 182, 1.

15. Gofman, J. W., Lindgren, F., Elliott, H., Mantz, W., Hewitt, J., Strisower, B., Herring, V., and Lyon, T. P., The role of lipids and lipoproteins in atherosclerosis. Science, 1950, 111, 166.

16. Gofman, J. W., Jones, H. B., Lindgren, F. T., Lyon, T. P., Elliott, H. A., and Strisower, B., Blood lipids and human atherosclerosis. Circulation, 1950, $2,161$.

17. Lindgren, F. T., Elliott, H. A., and Gofman, J. W., The ultracentrifugal characterization and isolation of human blood lipids and lipoproteins, with applications to the study of atherosclerosis. J. Phys. \& Coll. Chem., 1951, 55, 80.

18. Green, A. A., Lewis, L. A., and Page, I. H., A method for the ultracentrifugal analysis of $\alpha$ and $\beta$ serum lipoproteins. Federation Proc., 1951, 10, 191.

19. Lewis, L. A., Green, A. A., and Page, I. H., The $\alpha$ and $\beta$ lipoprotein pattern of normal and pathological human sera. Federation Proc., 1951, 10, 84.

20. Cogin, G. E., and Petermann, M. L., Estimation of serum lipoproteins by chemical and physical methods. Federation Proc., 1951, 10, 172.

21. Cohn, E. J., Gurd, F. R. N., Surgenor, D. M., Barnes, B. A., Brown, R. K., Derouaux, G., Gillespie, J. M., Kahnt, F. W., Lever, W. F., Liu, C. H., Mittelman, D., Mouton, R. F., Schmid, K., and Uroma, E., A system for the separation of the components of human blood: quantitative procedures for the separation of the protein components of human plasma. J. Am. Chem. Soc., 1950, 72, 465.

22. Beams, J. W., High-speed centrifuging. Rev. Mod. Phys., 1938, 10, 245.

23. Masket, A. V., A quantity-type rotor for the ultracentrifuge. Rev. Scient. Instr., 1941, 12, 277.

24. Hughes, T. P., Pickels, E. G., and Horsfall, F. L., A method for determining the differential sedimentation of proteins in the high speed concentration centrifuge. J. Exper. Med., 1938, 67, 941.

25. Randolph, M. L., Sampling specimens from an ultra- 
centrifuge by quick freezing. Phys. Rev., 1948, 74, 118.

26. Randolph, M. L., and Ryan, R. R., A slicer for sampling liquids. Science, 1950, 112, 528.

27. Ma, T. S., and Zuazaga, G., Micro-Kjeldahl determination of nitrogen. $A$ new indicator and an improved rapid method. Indust. \& Engin. Chem., Anal. Ed., 1942, 14, 280.

28. Popjak, G., and McCarthy, E. F., Osmotic pressures of experimental and human lipaemic sera. Evaluation of albumin-globulin ratios with the aid of electrophoresis. Biochem. J., 1946, 40, 789.

29. Barbour, H. G., and Hamilton, W. F., The falling drop method for determining specific gravity. J. Biol. Chem., 1926, 69, 625.

30. Schoenheimer, R., and Sperry, W. M., A micromethod for the determination of free and combined cholesterol. J. Biol. Chem., 1934, 106, 745.

31. Sobel, A. E., and Mayer, A. M., Improvements in the Schoenheimer-Sperry method for the determination of free cholesterol. J. Biol. Chem., 1945, 157, 255.

32. Stoddard, J. L., and Drury, P. E., A titration method for blood fat. J. Biol. Chem., 1929, 84, 741.

33. King, E. J., The colorimetric determination of phosphorus. Biochem. J., 1932, 26, 292.
34. Fiske, C. H., and SubbaRow, Y., The colorimetric determination of phosphorus. J. Biol. Chem., 1925, 66, 375.

35. Goldwater, W. H., Unpublished results.

36. Man, E. B., and Gildea, E. F., A modification of the Stoddard and Drury titrimetric method for the determination of the fatty acids in blood serum. J. Biol. Chem., 1932, 99, 43.

37. Randolph, M. L., Goldwater, W. H., Snavely, J. R., Sprague, C. C., and Turner, R. H., To be published,

38. Turner, R. H., Goldwater, W. H., Randolph, M. L., and Snavely, J. R., To be published.

39. Peters, J. P., and Van Slyke, D. D., Quantitative Clinical Chemistry. Vol. I, Interpretations. Williams \& Wilkins Co., Baltimore, 1946.

40. Lever, W. F., Gurd, F. R. N., Uroma, E., Brown, R. K., Barnes, B. A., Schmid, K., and Schultz, E. L., Chemical, clinical, and immunological studies on the products of human plasma fractionation. XL. Quantitative separation and determination of the protein components in small amounts of normal human plasma. J. Clin. Invest., 1951, 30, 99.

41. Albrink, M. J., Man, E. B., and Peters, J. P., Serum lipids in infectious hepatitis and obstructive jaundice. J. Clin. Invest., 1950, 29, 781. 